\title{
Article
}

\section{Chinese Marriage Migrants in Beifing's Cross-Strait Diplomacy}

\author{
Momesso, Lara
}

Available at http://clok.uclan.ac.uk/34005/

Momesso, Lara ORCID: 0000-0002-4042-9384 (2020) Chinese Marriage Migrants in Beijing's Cross-Strait Diplomacy. European Journal of East Asian Studies, 19 (1). pp. 161-184. ISSN 1568-0584

It is advisable to refer to the publisher's version if you intend to cite from the work. /10.1163/15700615-01901006

For more information about UCLan's research in this area go to http://www.uclan.ac.uk/researchgroups/ and search for < name of research Group>.

For information about Research generally at UCLan please go to http://www.uclan.ac.uk/research/

All outputs in CLoK are protected by Intellectual Property Rights law, including Copyright law. Copyright, IPR and Moral Rights for the works on this site are retained by the individual authors and/or other copyright owners. Terms and conditions for use of this material are defined in the policies page.

\section{CLoK}

Central Lancashire online Knowledge www.clok.uclan.ac.uk

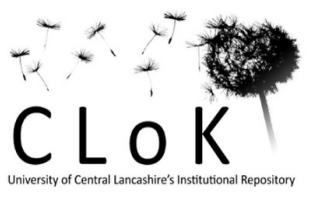




\title{
Chinese marriage migrants in Beijing's cross-Strait diplomacy
}

\author{
Lara Momesso \\ University of Central Lancashire
}

\begin{abstract}
The role of Chinese communities abroad has become increasingly significant in Beijing's public diplomacy strategy. This is not only the case of Overseas Chinese communities, but also for people who migrate between China and Taiwan. This paper will explore how a group of Chinese migrant women, the mothers, wives and daughters-in-law of Taiwanese citizens, have become a target of Beijing in its cross-Strait diplomacy and how they have responded to Beijing's initiatives. This paper gives a timely account of Beijing's non-traditional diplomacy in the context of cross-Strait relations, as a constructed and gendered process.
\end{abstract}

\section{Keywords}

Cross-Strait diplomacy; Taiwan; China; public diplomacy; marriage migration; cross-Strait family

\section{Introduction $^{1}$}

As cross-Strait movements and exchanges have increased considerably in the last couple of decades, China has had new opportunities to exert its influence on Taiwan. This has generated a series of concerns in the island, related to the negative impact that China may have on Taiwan's economy, democracy, sovereignty and freedom. Hence, the Taiwanese government has implemented a series of policies and put forward stances aiming to distance Taiwan from the sphere of influence of Beijing. Not only has the current president, Tsai Ying-wen, refused to explicitly recognise the core implications of the One China principle, but she has also worked to develop

1

Part of this research has been funded by the Confucius China Studies Programme -- 'Understanding China' Fellowship. The author would like to thank the two anonymous reviewers whose insightful comments contributed extensively to enhancing the quality of this paper. 
alternative economic policies that could contribute to diversifying Taiwan's sphere of economic and social exchanges and reduce the influence of China on the island. ${ }^{2}$ Beijing has responded to these initiatives in various ways: it has played with dollar diplomacy; it has reduced the flow of tourist groups from China; it has pressured several international companies to comply with the One China policy and standards. Less known are the formal and informal activities that Beijing has developed to attract cross-Strait communities with the purpose of promoting cross-Strait reunification. ${ }^{3}$ Throughout the 2000s, Beijing focused on Taiwanese communities in China, such as Taiwanese investors. ${ }^{4}$ More recently, it has placed new emphasis on better understanding the thoughts and sentiments of the people residing in Taiwan. Under the Three Middles and One Young Policy ($\llcorner\mathcal{f}$ ), it has targeted Taiwanese small and medium enterprises, the middle and lower classes, regular people in central and southern Taiwan, and young people in the island. ${ }^{5}$ Migrants of Chinese origin who moved to Taiwan for marriage in the last three decades constitute another category that has been courted by Beijing in its more recent cross-Strait diplomacy strategy. By building on the specificity of this case and applying a constructivist approach that considers state's actions and social actors' responses, this paper aims to better understand Beijing's public diplomacy in light of more recent changes across the Taiwan Strait.

In light of these reflections, this article seeks to answer the following questions: What is the role of Chinese marriage migrants in Beijing's public diplomacy in Taiwan? What does Beijing's

For instance, the New Southbound Policy is one of these: Alan H. Yang, 'Unpacking Taiwan's presence in Southeast Asia: the international socialisation of the New Southbound Policy', Issues and Studies: A Social Science Quarterly on China, Taiwan and East Asian Affairs 54, 1 (2018): 1840003-33.

3

Hsing-hsin Wu, Bridging the Strait: Taiwan, China, and the Prospects for Reunification (Hong Kong: Oxford University Press, 1994), 166.

Shu Keng and Gunter Schubert, 'Agents of Taiwan-China unification? The political roles of Taiwanese business people', Asian Survey 50, 2 (2010): 287-310.

Alan D. Romberg, 'Cross-Strait relations: portrayals of consistency calm on the surface, paddling like hell underneath', China Leadership Monitor 45 (Fall 2014): 1-26. 
changing narrative towards its migrants in Taiwan tell us about its public diplomacy strategy in the context of cross-Strait relations? How have Chinese migrants responded to Beijing's changing approach towards this social group?

Theoretically, this paper offers an empirical case to understand Beijing's public diplomacy as a gendered process in which state and migrants both have a role in shaping the modalities and final outcome of these practices. Along this line, this paper argues that against a migration phenomenon that involves a majority of women who move for family reasons, public diplomacy initiatives and narrative may acquire specific gender connotations: Beijing uses gendered narratives and activities when 'staging' cross-Strait marriage migrants and their families as symbols of crossStrait unity. Furthermore, this paper argues that Beijing's public diplomacy should be understood as a process, as marriage migrants are not just passive 'performers': although they may decide to reproduce the gendered nationalist narrative proposed by the state, it is important to ask what are the meanings they attribute to their performance, as they may be often located somewhere outside of the state's aims. Empirically, this paper offers rich data to understand how Beijing's cross-Strait diplomacy has also been targeting new groups located in Taiwan. In this context, Chinese migrants became important and easy-to-reach partners to serve the interests of Beijing.

This article proceeds as follows: the next section will offer a contextual background of the phenomenon of marriage migration between China and Taiwan. It will then summarise existing literature on public diplomacy, focusing on the specificity of Beijing's public diplomacy, with particular reference to diaspora diplomacy. The paper will then propose a new methodological framework designed to fill the gaps so far inherent in research on Beijing's public diplomacy. Finally, it will offer a discussion of the results obtained through this investigation and some broader conclusions to understand Beijing's public diplomacy in contemporary times.

\section{Mainland Spouses in Beijing's Cross-Strait Diplomacy}


Cross-Strait marriage migration is part of broader marriage migration patterns that have emerged in the Asian region and globally during the last decades. ${ }^{6}$ Yet, as a phenomenon occurring in the context of post-Cold War China-Taiwan relations, it has evolved rather differently from other regional marriage migration patterns. This phenomenon started in the late 1980s, after the lifting of a ban of almost forty years on social and economic exchanges between China and Taiwan. Since the early days, the issue of Taiwan's unresolved sovereignty, which does not allow the Taiwanese national community to enjoy full recognition as a nation, has deeply interfered with the evolution of this phenomenon. As citizens from mainland China, Taiwan's major political enemy, mainland spouses have been treated as 'exceptional subjects' in the island, hence they have been subjected to a differentiated legal treatment ${ }^{7}$ and constructed as a political enemy, ${ }^{8}$ features that do not necessary apply to migrants from other countries. The literature broadly explores how mainland spouses have negotiated this exceptional condition with the Taiwanese state and, particularly, how the Taiwanese state uses gender as a way to limit the margin of action of these migrants. ${ }^{9}$ Yet, with a few

6

Yen-fen Tsai, 'Marriage migration to East Asia. Current issues and propositions in making comparisons', in Asian Cross-border Marriage Migration. Demographic Patterns and Social Issues, eds Melody Lu and Wen-shan Yang (Amsterdam: Amsterdam University Press, 2010), 3145. 7

Sara Friedman, 'Marital immigration and graduated citizenship: post-naturalization restrictions on mainland Chinese spouses in Taiwan', Pacific Affairs 83, 1 (2010): 73-93; Sara Friedman, Exceptional States. Chinese Immigrants and Taiwan Sovereignty (Oakland: University of California Press, 2015); Shumei Shih, 'Gender and a new geopolitics of desire: the seduction of Mainland women in Taiwan and Hong Kong media', Signs 23, 2 (1998): 287-319; Wang-ying Yang and Ping-rong Lee, 'The citizenship dilemma of mainlander spouses in Taiwan: the conspiracy of nationalism and patriarchy (大陸配偶的公民權 困境一 國族與父權的共謀)' (in Chinese), Taiwan Democracy Quarterly (臺灣民主季 刊) 6, 3 (2009): 47-86. 8

Hsiao-chuan Hsia, 'Imaged and imagined threat to the nation: the media construction of the “foreign brides' phenomenon" as social problem in Taiwan', Inter-Asia Cultural Studies 8, 1 (2007): 55-85; Shu-mei Shih, 'Gender and a new geopolitics of desire'. 9

Isabelle Cheng, Lara Momesso and Dafydd Fell, 'Asset or liability: transnational links and political participation of foreign-born citizens in Taiwan', International Migration (2018); https://doi.org/10.1111/imig.12534; Shan-Jan Sarah Liu, 'Chinese migrant wives in Taiwan: claiming entitlements, resisting inequality, and rejecting citizenship', International Feminist Journal of Politics 21, 4 (2019): 617-38; Lara Momesso and Isabelle Cheng, 'A team player pursuing its own dreams: rights-claim campaign of Chinese migrant spouses in the migrant movement before and after 2008', in Taiwan's Social Movements under Ma Ying-jeou: From the 
exceptions, ${ }^{10}$ the scholarship does not take an interest in this group's negotiations with the sending state. Most probably this is related to the novelty of this aspect of the phenomenon: busy courting Taiwanese investors on the mainland as potential economic and political actors, Beijing did not show any particular interest in mainland spouses at least until the mid-2000s.

There may be several reasons behind Beijing's lack of engagement with cross-Strait marriage migrants in the early years. First, the number of people involved in this phenomenon was still very low until the end of the 1990s: 240 spouses in 1992; 300 in $1993 ; 1,800$ in $1997 .{ }^{11}$ Second, in the early years, a majority of these migrants were lower-class women from rural areas, often divorced, who married Taiwanese men from lower social classes, such as veterans, fishermen and farmers. For a country that was striving to redefine its image vis-à-vis Western powers as well as Taiwan, ${ }^{12}$ the low economic and social status of these migrants and their families could have been a cause of shame rather than pride, so Beijing may have chosen to neglect this undesirable social group. Third, these movements involved, in the majority of cases, women who crossed the border for marriage and family formation. Their gendered identity, as mothers and wives, may have discouraged Beijing from targeting this group who did not seem to bring any economic or political contribution to its nation-building project. ${ }^{13}$ Yet something changed in the mid-2000s.

Wild Strawberries to the Sunflowers, ed. Dafydd Fell (Abingdon: Routledge, 2017); Sara Friedman, 'Marital immigration and graduated citizenship'; Wang-ying Yang and Ping-rong Lee, 'The citizenship dilemma of mainlander spouses in Taiwan'.

10

Lara Momesso and Chun-yi Lee, 'Transnational mobility, strong states and contested sovereignty: learning from the China-Taiwan context', Asian and Pacific Migration Journal 26, 4 (2017): 459-79; Lara Momesso, 'Marriage, migration, and state interests: reflections from the experiences of marriage migrants from the People's Republic of China in Taiwan', Asiatische Studien 70 (2016): 903-20.

11

Edward Jow-Ching Tu and Shaomin Li, 'Inter-regime marriage and mobility: the case of Mainland China and Taiwan', Journal of Contemporary China 8, 22 (1999): 499-516. 12

Zheng Wang, 'The Chinese Dream: concept and context', Journal of Chinese Political Science 19 (2014): 1-17, 7. 
In 2004, twelve representatives of the Marriage Association of the Two Sides of China ("

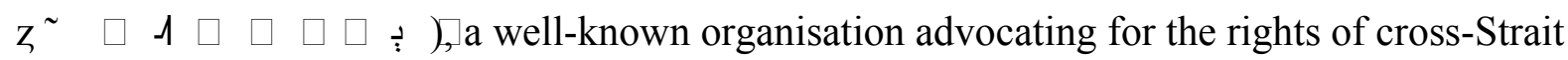
families in Taiwan, were invited to attend a meeting with representatives of the Taiwan Affairs Office, the Ministry of Civil Affairs and the All China Women's Federation in Beijing. ${ }^{14}$ Similar activities were organised in the following years, and other organisations were also invited. As these events became more frequent and more organisations were invited, they also diversified in form to include exchange events celebrating Chinese New Year, group wedding ceremonies, delegations of mainland spouses visiting their home towns ${ }^{15}$ and summer and winter camps for the children of cross-Strait families. ${ }^{16}$

Another shift occurred in China in 2012, when the Cross-Strait Marriage Family Forum (\$ $1 \square \square^{2} z \quad$ ) was launched, as an annexe of the Cross-Strait Forum. The Cross-Strait Forum is an important event between mainland China and Taiwan, held, usually each year, since 2009. At this formal occasion, government officials, academics, specialists, social practitioners and civil society organisations from China and Taiwan gather to discuss issues related to interaction, economic and trade exchanges and cultural integration across the Taiwan Strait. Following this first event, the Cross-Strait Marriage Family Forum has been repeated each year. Furthermore, as a follow-up, Beijing established a nation-wide body specialising in cross-Strait families, the CrossStrait Marriage Family Association ( $\dot{\jmath} \quad . \quad 1 \quad \square \frac{\%}{\mathfrak{l}} \quad$ ), under the authority of the Ministry

Lara Momesso and Chun-yi Lee, 'Nation, migration, identity: learning from the cross-Strait context', International Migration (2019); https://doi.org/10.1111/imig.12576.

14 15

Interview, 31 May 2011, Taipei.

Some of the initiatives of this type listed in the Cross-Strait Marriage Family Association Periodical are: 'Joy back home, one family between Hunan and Taiwan' (欢喜回娘家、湘台一家 亲) in October 2014; 'Taiwan brides from Chongqing back home' (台湾重庆籍新娘故乡行) in August 2014; 'Jiaxing spouses from cross-Taiwan marriages return home' (涉台婚姻嘉兴籍配偶故 乡行) in August 2015.

Cross-Strait Marriage Family Association (CSMFA), Services for Cross-Strait Marriage and Family (兩岸婚姻家庭服務) (Beijing: Cross-Strait Marriage Family Association, 2015), 6-11. 


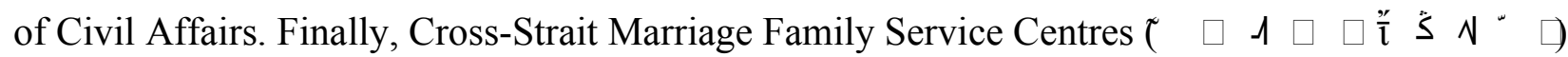
were set up in several Chinese provinces and cities with the purpose of facilitating an exchange of information on cross-Strait families, offering legal advice and aid, providing information, improving the quality of cross-Strait marriages and family life, and developing a forum on policies related to cross-Strait families. ${ }^{17}$ The creation of this government apparatus was also accompanied by repeated discursive practices. Media material related to these events started to be published and broadcast in state-owned media. A magazine, the Cross-Strait Marriage Family Association Periodical $\quad 1 \quad \square \stackrel{2}{\mathrm{l}} \quad \square \square$ ), was published each year with the purpose of providing information and updates on cross-Strait families and on the exchanges that were organised throughout the year.

Clearly, in a period that spanned less than ten years, Beijing showed concern and invested resources in cross-Strait families as never before. It did this first by establishing connections with cross-Strait marriage migrants' civic organisations in Taiwan, then by creating formal opportunities and events to interact with these migrants on Chinese territory, and finally by creating a positive narrative about cross-Strait families in the public media. All these activities can be framed under the umbrella of public diplomacy.

\section{Theoretical Framework}

Public diplomacy refers to strategies developed by state actors and aimed at generating power, attracting resources, starting dialogue and establishing long-term relationships with the publics within and beyond national borders. ${ }^{18}$ Traditional public diplomacy theories are based on state-

17

Retrieved from the Cross-Strait Family Association website, http://c-

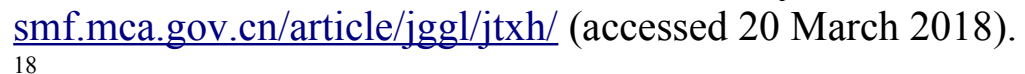

Shin-wha Lee, 'The theory and reality of soft power: practical approaches in East Asia', in Public Diplomacy and Soft Power in East Asia, eds Jan Melissen and Sook Jong Lee (New York: Palgrave Macmillan, 2011), 11-32; Sook Jong Lee and Jan Melissen, 'Introduction', in Public 
centred analyses: the most important actor is usually seen as the state, the main concerns are focused on power politics and national security, and the final outcome seeks to change the policy of foreign governments. ${ }^{19}$ Yet, more recently, attention has turned to ideational and cultural programmes aimed at targeting social actors in order to attract their support and recognition. ${ }^{20}$ These new practices have been named as network public diplomacy ${ }^{21}$ or new public diplomacy. ${ }^{22}$ Regardless of the names, these practices suggest an important shift from the traditional understanding of public diplomacy, as a sphere solely controlled by state actors, to a broader understanding that also acknowledges the 'multiple stakeholders and polylateral operations of diplomacy'. ${ }^{23}$ In the literature on new public diplomacy, migrants, diaspora and transnational communities have become an increasingly important focus, ${ }^{24}$ to the point that a new expression, diaspora diplomacy, has been coined..$^{25}$

Exploring these forms of public diplomacy directed to social actors, though, also means gaining insight into the strategic motivation behind social actors' engagement in a state's public

Diplomacy and Soft Power in East Asia, ed. Jan Melissen and Sook Jong Lee (New York: Palgrave Macmillan, 2011), 1-10.

19

Seong-Hun Yun and Elizabeth L. Toth, 'Future sociological public diplomacy and the role of public relations: evolution of public diplomacy', American Behavioural Scientist 53, 4 (2009): 493-503.

20

Ingrid D'Hooghe, Diplomatic Studies: China's Public Diplomacy (Leiden: Brill Nijhoff, 2014), 35 .

21 77-87.

Jamie Metzl, 'Network diplomacy', Georgetown Journal of International Affairs 2 (2001):

Jan Melissen, ed., The New Public Diplomacy: Soft Power in International Relations (Basingstoke: Palgrave Macmillan, 2007). 23

Elaine L. Ho and Fiona McConnell, 'Conceptualizing "diaspora diplomacy": territory and populations betwixt the domestic and foreign', Progress in Human Geography 43, 2 (2019), 241.

Seong-Hun Yun and Elizabeth L. Toth, 'Future sociological public diplomacy and the role of public relations', 500 .

25

Elaine L. Ho and Fiona McConnell, 'Conceptualizing "diaspora diplomacy”, 236. 
diplomacy initiatives.

Turner contributes extensively in this regard. By building on the idea of 'politics of performance', he observes how the Rwandan state 'staged' its diaspora as agents of economic development, as ambassadors abroad and as a source of knowledge and skills, with the purpose of asserting the state sovereignty domestically and abroad. ${ }^{26}$ In his paper, Turner also explores the perspectives of migrants who engaged in the Rwandan state's public diplomacy practices. Yet little is said with regard to how migrants strategised, reproduced or challenged governmental efforts.

In this regard, Scheiwiller expands Turner's model. ${ }^{27}$ Through the concept of performativity, which refers to repeated discursive practices that either delineate or reinforce societal agendas, expectations or norms, she explains how state policies are translated into social groups' actions. ${ }^{28}$ Hence, state policies are seen as the outcome of a bidirectional process including the top-down definition of an official ideology through 'staging' and the bottom-up interpretation of it through 'performance'. Scheiwiller adds to Turner's model by reflecting on how the performative act may not only reinforce ideology but also hide a personal aim that may lie somewhere outside the state's objectives.

Scheiwiller's main point is that social actors may have their own agenda when performing a state's ideology. She identifies three main types of performativity: citationality, when a person is framed and moulded into perceived constructions of identity, for instance through propaganda, expected behaviour or societal and religious norms; materialisation, when individuals actively reproduce state policies through their discursive and material practices; apparatuses, when

26

Simon Turner, 'Staging the Rwandan diaspora: the politics of performance', African Studies 72, 2 (2013): 235-6.

Staci Gem Scheiwiller, 'Introduction: setting the stage', in Performing the Iranian State: Visual Culture and Representations of Iranian Identity, ed. Staci Gem Scheiwiller (New York: Anthem Press, 2013).

28

Staci Gem Scheiwiller, 'Introduction: setting the stage', 11. 
individuals actively engage with institutions. ${ }^{29}$ Using these dimensions, the author shows how Muslim women may have different levels of engagement when they 'perform' a state's ideologies, from less aware actions to full agency in developing initiatives, from passive reproduction to redefinition of a state agenda.

These reflections are important to understand Beijing's more recent public diplomacy strategies. Public diplomacy is an essential part of China's foreign policy and diplomacy, a way to create understanding, respect and support for its political model and policies domestically and internationally. ${ }^{30}$ Chinese communities abroad have played an important role in Beijing's public diplomacy strategy. As Louie stresses, 'as China emerged from its socialist isolation in the early 1980s, it was faced with the challenge of reaching out once more to an overseas population that had good reason to mistrust the PRC government'. ${ }^{31}$ Hence, right after the opening up to the market economy, Overseas Chinese were expected to resolve the contradictions between past and present economic policies and, through investments, to contribute to the economic development of a still relatively poor China. ${ }^{32}$ More recently, they have been targeted for other reasons, as returnees to be 29 30

Staci Gem Scheiwiller, 'Introduction: setting the stage'.

Ingrid D'Hooghe, 'The rise of China's public diplomacy', in The Limits of China's Soft Power in Europe: Beijing's Public Diplomacy Puzzle, ed. Ingrid D'Hooghe (Hague: Netherlands Institute of International Relations, 2014), 3-4; Shin-wha Lee, 'The theory and reality of soft power', 24-7; Hong Liu, 'An emerging China and diasporic Chinese: historicity, state, and international relations', Journal of Contemporary China 20, 72 (2011): 813-32; Joshua Cooper Ramo, The Beijing Consensus: Notes on the New Physics of Chinese Power (London: Foreign Policy Centre, 2004).

31

Andrea Louie, Chineseness across Borders: Renegotiating Chinese Identities in China and the United States (Durham, NC: Duke University Press, 2004), 50. 32

Maggi W.H. Leung, 'Academic mobility for development as a contested notion: an analysis of the reach of the Chinese state in regulating the transnational brains', Tijdschrift voor Economische en Sociale Geografie 105, 5 (2014), 558-72; Hong Liu, The Chinese Overseas (Vol. 4: Homeland Ties and Agencies of Interaction) (Abingdon: Routledge, 2006); Biao Xiang, Promoting Knowledge Exchange through Diaspora Networks (the Case of People's Republic of China) (Report for the Asian Development Bank) (Oxford: ESRC Centre on Migration, Policy and Society, University of Oxford, 2005); Rui Yang and Anthony R. Welch, 'Globalisation, transnational academic mobility and the Chinese knowledge diaspora: an Australian case study', 
hired in China ${ }^{33}$ or as promoters of Chinese culture and supporters of Chinese political interests abroad. ${ }^{34}$ A sub-category in Beijing's public diplomacy is cross-Strait diplomacy: with a rapprochement between China and Taiwan in the last thirty years, public diplomacy has become an important tool for Beijing to pursue its One China policy. In this context, cross-Strait migrant communities have been an important target in Beijing's cross-Strait diplomacy. ${ }^{35}$ In light of these reflections, this paper will build on Turner's and Scheiwiller's models to interpret how the bidirectional interaction between state and migrants is enacted: on the one hand, how Beijing 'staged' its marriage migrants and, on the other hand, how Chinese marriage migrants 'performed' the state's ideology in their practices. This bidirectional analysis will offer an alternative perspective to shed light on Beijing's public diplomacy, not only as a sphere to explore how it influences others, but also as a terrain to investigate how social actors strategise Beijing's public diplomacy practices.

\section{Methodology}

Discourse: Studies in the Cultural Politics of Education 31, 5 (2010): 593-607.

33

Biao Xiang, 'A new mobility regime in the making: what does a mobile China mean to the world?', Global Governance 10 (2007): 1-19, 14.

34

Ingrid D'Hooghe, 'The rise of China's public diplomacy', 160-62; Emmanuel Ma Mung, 'Chinese migration and China's foreign policy in Africa', Journal of Chinese Overseas 4, 1 (2008): 105; Leo Suryadinata, The Rise of China and the Chinese Overseas. A Study of Beijing's Changing Policy in Southeast Asia and Beyond (Singapore: IEAS Publishing, 2017), 23-37; Gungwu Wang, 'Greater China and the Chinese overseas', The China Quarterly, Special Issue: Greater China 136 (December 1993): 926-48; Biao Xiang, 'A new mobility regime in the making'; Hong Liu, 'An emerging China and diasporic Chinese', 823-4. 35

Shu Keng and Gunter Schubert, 'Agents of Taiwan-China unification?'; Gang Lin, Ramon H. Myers, Terry Cooke and Tun-jen Cheng, 'Cross-Strait economic ties: agent of change, or a Trojan horse?' Asia Program Special Report, no. 118 (Princeton, NJ: Woodrow Wilson Center, 2003), 1-18; Emerson M.S. Niou, Peter C. Ordeshook and Guofu Tan, 'Taiwanese investment in mainland China as a policy tool', Issues and Studies 28, 8 (1992): 14-31; Hsing-hsin Wu, Bridging the Strait: Taiwan, China, and the Prospects for Reunification (Hong Kong: Oxford University Press, 1994), 166; Yu-Shan Wu, 'Mainland China's economic policy toward Taiwan: economic need or unification scheme?' Issues and Studies 30, 9 (1994): 29-49. 
This paper treats the phenomenon of cross-Strait marriage migration as a case study: ${ }^{36}$ the specificity of this phenomenon makes a good case to reflect on the peculiarity of Beijing's public diplomacy in the context of cross-Strait relations and of a gendered form of migration. This paper triangulates two sets of data to understand both sides of the phenomenon ('staging' and 'performing').

To explore how Beijing 'staged' its migrants, the author collected and analysed the content of different written texts published in state-controlled sources and concerning the interest group. The main source of reference is the monthly periodical Relations Across Taiwan Straits ( _ . 6 $\$$, RATS). Produced under the aegis of the Taiwan Affairs Office and sponsored by the People's Republic of China Association for Relations Across the Taiwan Strait, this periodical reflects Beijing's official voice with regard to cross-Strait relations. The articles selected from this periodical were also integrated with other written material published by the Ministry of Civil Affairs and the Cross-Strait Marriage Family Association. These include online and written material. For instance, the Cross-Strait Marriage Family Association publishes a yearly magazine, summarising the main activities organised for cross-Strait families each year. Finally, these data were also integrated with one in-depth interview carried out with a representative of the Cross-Strait Marriage Family Association in Fujian province. Most of the material was collected in the period between January and October 2016.

To explore how migrants 'performed' Beijing's discursive and material practices, the paper relies on the collection of qualitative data during various ethnographic fieldwork activities based on participant observation and in-depth interviews carried out with marriage migrant communities in civic organisations, family homes and other sites in Taiwan (2007-16) and, more recently, in China (2016).

The texts collected from RATS cover the period 1997-2016 and the search was based on the 36 Bill Gillham, Case Study Research Methods (London: Bloomsbury., 2000). 
identification of specific keywords in article titles, including cross-Strait marriage $\left(\begin{array}{ll}-1 & \text { ) (ten }\end{array}\right.$

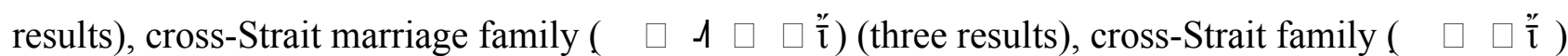
(ten results), mainland bride ( $\square \overline{\mathrm{l}}{ }^{\prime} \dot{\Gamma}$ ) (three results), mainland spouse ( $\square \overline{\mathrm{l}} \circ$ "H) (three results),

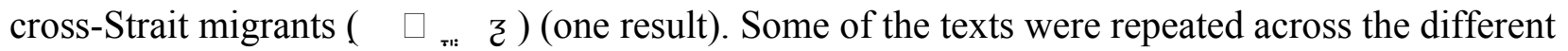
keyword searches. These keywords were decided on the basis of preliminary research through different academic and governmental sources, which revealed that in Beijing's official narrative, as well as in mainland Chinese academic discourse, the most common expressions to refer to this phenomenon have been cross-Strait family and cross-Strait marriage family. With regard to this point, it is important to emphasise the fact that different terminologies have developed in China and in Taiwan to refer to the same phenomenon, reflecting the different political implications that this phenomenon may have on each side of the Taiwan Strait. Hence, if in China the focus has been on the family (cross-Strait marriage; cross-Strait family; cross-Strait marriage family), in Taiwan it has been on individuals and their migrant identity, with more common expressions being mainland spouse, mainland bride, new immigrant, new resident. In China, in earlier years, another expression was common, namely veteran marriages ( $\quad X 1 \quad$ ), to refer to Chinese women who married Taiwanese veterans. Yet research with this keyword throughout the RATS periodical did not offer any result, confirming the point mentioned above with regard to the invisibility of this phenomenon in Beijing's public narrative in the early years. However, it is interesting to note that this expression is used within texts to refer to an earlier phase when cross-Strait marriages were motivated by economic reasons. Out of all the texts which were collected, twelve were selected as directly relevant to contemporary cross-Strait marriages. The texts were analysed qualitatively, by applying a content analysis based on the identification of recurrent themes within the texts. These data were integrated with the material collected from governmental websites monitored up to the year 2016.

To preserve the anonymity and confidentiality of informants, pseudonyms have been used throughout this paper. 


\section{The Cross-Strait Family in Beijing's Public Diplomacy}

The twelve texts collected from the RATS periodical can be divided in two main groups: articles published before and after 2010. A clear distinction exists in the narrative between these two periods, reflecting the change in Beijing's approach towards cross-Strait marriage migrants after 2010. The six articles published before 2010 do not seem to have any particular political connotations. These are descriptive accounts explaining a phenomenon that was still relatively unknown in Chinese public debate. As Beijing was still developing its understanding of cross-Strait marriage migration by inviting civic organisations' representatives to meetings in China, these articles rely extensively on the public narrative that had developed in Taiwan when cross-Strait marriage migration boomed and started to be perceived as a political problem. The main themes addressed by these articles include mainland spouses' economic hardships, the unfair treatment they were subjected to on the island, and the protests and rallies organised by migrant civic organisations. Some articles include pictures that reinforce this narrative, immortalising mainland spouses during protests and rallies. ${ }^{37}$ Attempts to explain mainland spouses' low status in Taiwan tend to focus on migrants' personal and family status and avoid engaging with the sensitive theme of cross-Strait politics. For instance, one of the articles reads:

I think that the main problem is that mainland spouses are a weak group in Taiwan and their voice is weak too. In Taiwan, they are mainly married to Taiwanese from lower classes.

There is just a minority married to doctors, lawyers and engineers. ${ }^{38}$

After 2010, the narrative changes extensively. In March 2010, in an article titled 'The spring breeze

37

'Discrimination against mainland spouses should not become a popular feeling (歧视大陆配偶不得人心)', Relations Across Taiwan Straits (RATS), February 2002, 22; 'The mainland spouses I have seen (我所看到的大陆新 娘)', RATS, August 2004, 45-6; 'Easing restrictions on the right to work: a new start for mainland spouses (放宽工作 圈：大陆配偶新开端)', RATS, November 2008, 37. 38

'The mainland spouses I have seen (我所看到的大陆新娘)', 47. 
dissolves many layers of snow: the water of the sea links hearts across the Strait. Looking at crossStrait marriages from the cross-Strait movements of a common person', the political implications of cross-Strait marriages emerge clearly through the lines:

Mainland spouses are Taiwan's daughters and sons in law, yet they also are the daughters and sons of the mainland. They are the bridge that links together the blood of both sides of the Strait. Waiting for peaceful developments across the Strait, we need to treat these ordinary people well, as they are part of a greater flow of exchanges. Because it is their straightforward blood relationship that can most transcend the Strait, resolve misunderstanding, and permanently connect the people on the two sides. ${ }^{39}$

In the other five articles published after 2010, exceptionally positive expressions are used to describe mainland spouses and cross-Strait families: 'beautiful cross-Strait marriages', 'harmonious and happy cross-Strait families'; their blossoming after a long period of lack of exchanges across the Taiwan Strait is seen as 'bamboo shoots after the rain'; their significance in cross-Strait unification is stressed by calling them the 'fourth cross-Strait link'. Previous accounts of sorrow and struggle are replaced by successful and positive stories of independent and ambitious individuals deserving and demanding respect:

Before, they often complained about unfairness, now they rely on themselves and on their right to speak out. Before, they endured patiently, now they protest against unfairness. Before, they adapted to the requests of their husbands and they relied on them, now they are economically independent and they rely on themselves ... From past 'mainland sisters' to 'mainland brides' to contemporary 'mainland spouses' this change of their names reflects the changes they went through. They obtained increased respect, and this respect was earned

39

'The spring breeze dissolves many layers of snow: the water of the sea links hearts across the Strait. Looking at cross-Strait marriages from the cross-Strait movements of a common person (春风终解千层雪, 海水犹连两岸心。从两岸往来大流中的小人物看两岸婚姻)', RATS, March 2010, 45. 
through their bodies and experiences. ${ }^{40}$

In the same article, celebrities are used as testimonials to the success of these marriages; examples include Chen Yujia ( ${ }^{\Theta} \quad$ " ) , a television host from Taiwan who married Jiang Nanchun ( ${ }^{\mathrm{d}}$ g “ ), founder of a media company in China, and the Taiwanese actress Big S ( $\square$ S), who married Wang Xiaofei ( $\quad \square \quad$ ), a handsome and successful entrepreneur from Beijing. ${ }^{41}$ Romantic and suggestive images with wedding photography immortalising smiling grooms and brides wearing Western-style dresses are incorporated in the article. ${ }^{42}$

The literature argues that, in the same years, Chinese media reports had become more frequent and positive in tone with regard to cross-Strait families. For instance, the image presented by the documentary television serial Yuanfen, broadcast by Channel 4 of the state-run China Central Television station, showed an attempt to reframe mainland spouses in positive terms, as women with careers and as good daughters-in-law, wives and mothers. ${ }^{43}$ Clearly, these changes in the public narrative reflect the efforts that Beijing was making in those years to formalise cross-Strait families' inclusion in the state apparatus, and hence in the national community. It is argued that one of Beijing's main points with regard to cross-Strait relations revolved around the idea that Taiwan is 'really or naturally or culturally-historically a part of China and that the island's long separation from mainland rule is therefore anomalous'. ${ }^{44}$ Within this narrative, cross-Strait marriages and

40 51.

'Sadness and love in “mainland spouse” (痛并爱着的'大陆新娘')', RATS, September 2012, 41 42

"Sadness and love in "mainland spouse", 51.

'Serving cross-Strait sweet cause and common effort. Interview with Dou Yupei, Deputy Minister for Civil Affairs and President of the Cross-Strait Marriage Family Association (为服务跨 越海峡的甜蜜事业而共同努力。访民政部副部长、海峡两岸婚姻家庭协会会长赎玉沛)', RATS, September 2012, 41; 'Sadness and love in "mainland spouse", 50-52.

43

Pan Wang, 'Media presentations of cross-Strait marriage in contemporary China', China Media Research 11, 2 (2015): 17-28.

44

Jacques deLisle, 'Soft power in a hard place: China, Taiwan, cross-Strait relations and US 
families could have an important role: they could legitimise the idea of blood continuity and unity across the Taiwan Strait. Hence, Beijing not only integrated cross-Strait marriage migrants into its nation-building project, but it also strategised the gendered nature of this form of migration. In contrast to the approach of the Taiwanese government, which used gender as a means to exclude these migrants from the political activities of the national community, ${ }^{45}$ Beijing strategised the gendered nature of this phenomenon and translated it into a potential for inclusion in the national community and in the nation-building project. In other words, their reproductive function became their strength in Beijing's narrative, as they contributed to reproducing the 'common ancestral blood' that characterises the Chinese national community envisaged by Beijing in its One China ideal. And this clearly emerges through some of the articles in the RATS periodical. For instance, in an article reporting an interview with Dou Yupei, Deputy Minister of the Ministry of Civil Affairs and President of the Cross-Strait Marriage Family Association, it is stated:

Cross-Strait families strengthen the blood linkages between compatriots across the Strait, they continue the common ancestral blood of the Chinese nation. They pass on to future generations the common mark of the Yellow emperor. Let the numerous cross-Strait families condense into each other [and] join together through love and affection. Cross-Strait marriages constantly affect friends and colleagues on both sides, favouring mutual understanding, ending misunderstanding, increasing common awareness of each other, and magnifying true sentiments between compatriots. Each cross-Strait spouse is a promoter of human exchanges across the Strait. Each cross-Strait family is a public example of crossStrait affection. We can say that the cross-Strait family is the most accurate and existing proof of 'one family across the two shores', ${ }^{46}$

policy', Orbis 54, 4 (Fall 2010): 511.

Cheng et al., 'Asset or liability'; Shan-Jan Sarah Liu, 'Chinese migrant wives in Taiwan'; Sara Friedman, 'Marital immigration and graduated citizenship'.

'Serving cross-Strait sweet cause and common effort', 41. 
With cross-Strait families having been staged as symbols of a unified and glorious nation, now the call was on them to participate in Beijing's nation-building project. In another article, summarising the main points of the first general meeting of the Cross-Strait Marriage Family Association, Dou Yupei is reported as saying: 'cross-Strait peaceful development needs the support and effort of cross-Strait families, and the happiness of cross-Strait families cannot exist without peaceful unification across the Strait' ${ }^{47}$ This was further emphasised in 2015: in that year, the Fourth CrossStrait Family Forum was organised, with the theme 'The Cross-Strait Dream ( $\mathrm{k} \sim$ )', extending the main features of social cohesion, economic prosperity and people's well-being, ${ }^{48}$ peculiar to the Chinese Dream, to the context of cross-Strait relations.

As Scheiwiller suggests, the state manifests itself through the repetition of actions that become commonplace and pervade everyday life; rituals and regular events are an important feature in this process. ${ }^{49}$ Beijing's efforts to reach mainland spouses, through regular events in Chinese territory and visits of cross-Strait marriage migrants' organisations in Taiwan, can be seen as an act of sovereignty, a way to magnify its own power by forming new alliances across the Taiwan Strait. Yet, as Turner stresses, 'sovereignty is not given a priori, and such manifestations need to be reenacted in order to maintain sovereignty'. ${ }^{50}$ To what extent and in what way did mainland spouses reproduce Beijing's acts of sovereignty?

\section{Marriage Migrants' Responses: Appropriating the Official Narrative}

47

'Sharing happiness, cheering up for love. Report of the second Cross-Strait Marriage Family Forum (分享幸福为爱加油。第二届两岸婚姻家庭论坛侧记)', RATS, July 2013, 54.

48

Ane Bislev, 'The Chinese Dream: imagining China', Fudan Journal of Human and Social Sciences 8 (2015): 586; Joseph Gregory Mahoney, 'Interpreting the Chinese Dream: an exercise of political hermeneutics', Journal of Chinese Political Science 19, 27 (2014); Zheng Wang, 'The Chinese Dream: concept and context', 7.

49

Staci Gem Scheiwiller, 'Introduction: setting the stage', 12.

50

Turner, 'Staging the Rwandan diaspora', 266. 
The informants seemed to appreciate Beijing's efforts. When Chinese authorities started to reach out to mainland spouses' organisations in Taiwan, the informants generally showed a positive attitude towards Beijing's initiatives. For many of them, it was a matter of gaining recognition in their homeland and, by identifying in a new, modern and strong China, gaining recognition in Taiwan too. Particularly in Taiwan, informants saw in this an opportunity to push their public image beyond that of the usual mothers, wives and daughters-in-law of Taiwan: following the narrative of Beijing, they started to think of themselves as channels across the Taiwan Strait and valuable contributors to the economic, cultural and social development of both Taiwan and China. ${ }^{51}$ In Gamlen's words, 'a sense of common belonging to the home-state ${ }^{152}$ was established between Beijing and marriage migrants. This entitled Beijing to govern its migrants by relying on their support in promoting cross-Strait unification in Taiwan. Not all marriage migrants the author has met throughout the years showed an active engagement with Beijing's call to action.

Usually informants limited their pro-China sentiments to private conversations. Yet, in some instances, it is possible to see mainland spouses embracing Beijing's call to action, falling into Scheiwiller's second dimension of engagement with state policies (materialisation). ${ }^{53}$ For instance, when, in June 2014, Zhang Zhijun, Director of the Taiwan Affairs Office, went on a tour in Taiwan, groups of cross-Strait marriage migrants gathered to show their support, in opposition to the antiChina demonstrations that arose in various places in Taiwan. An informant who seemed to have strong patriotic sentiments, whom this article will name Xuefei, decided to go a step further and

51

Lara Momesso, 'Marriage, migration, and state interests: reflections from the experiences of marriage migrants from the People's Republic of China in Taiwan', Asiatische Studien 70 (2016): 903-20.

52

Alan Gamlen, 'Diaspora engagement policies: what are they, and what kinds of states use them?' Working paper no. 06-32 (Oxford: University of Oxford, Centre on Migration, Policy and Society, 2006); http://essays.ssrc.org/remittances anthology/wpcontent/uploads/2009/08/Topic 19_Gamlen.pdf (accessed 20 May 2020), 7.

Staci Gem Scheiwiller, 'Introduction: setting the stage'. 
engage with state institutions: she established a political party in Taiwan, with the main goal of contributing to the ideal of cross-Strait unification. As she stated during an interview, 'unification is one country, one China. It is not sufficient to have cross-Strait development. We need to reach cross-Strait unification, under the Communist Party obviously. ${ }^{154}$

Despite the fact that not all informants decided to stand for Beijing in public, those who did so, through their repetitive performative acts, reinforced the state's ideology and contributed to reproducing its act of sovereignty.

On the other hand, digging below the surface, the meanings that migrants attributed to these actions could be different. On several occasions, mainland spouses saw in Beijing's seductive attentions and narrative an opportunity to push forward their own agenda, which did not necessarily fully match the goals of Beijing.

\section{Migrants' Agenda: Questioning, Changing, Strategising}

Torab suggests that, although ideology relies on the existence of repetitive performative actions, the meaning that social actors attach to their performance may be located somewhere outside of the original aims conceived by the state. ${ }^{55}$ The narratives of the informants resonate with this principle. While participating in Beijing's activities, the majority of informants were driven by personal concerns and they often transformed these exchanges into a platform to voice their frustrations and seek a solution to their problems. As the leader of a group from one of the civic organisations invited to China explained:

Spouses treat these kinds of meetings as good opportunities to file their own complaints.

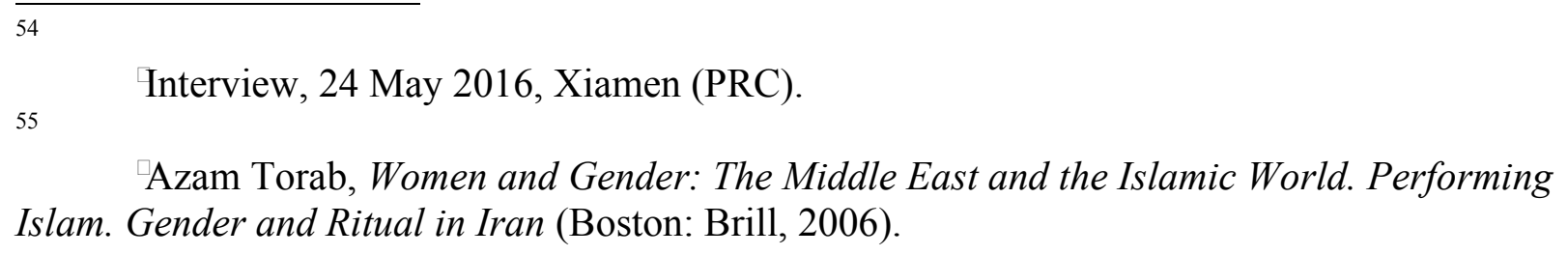
Islam. Gender and Ritual in Iran (Boston: Brill, 2006). 
They talk on behalf of their village, town, or they discuss personal situations, about arguments on local issues, or maybe about their provinces in China. They do not bring in the problems of Taiwan! They know that the central government cannot help them with the problems they are facing in Taiwan; the government can only help with their cases on the mainland. We had an argument about this, because I told them that these are official visits and we should not talk about these issues, and some of them told me, 'Well, I know the Communist Party better than you, so do not interfere in this issue! ${ }^{156}$

On other occasions, migrants were thrilled by the idea of joining events in China and being 'staged' there, as these could open up new opportunities both in China and Taiwan. Xuli, a woman from Chengdu, had a chance to attend the Cross-Strait Marriage Family Forum twice, in Xiamen in 2013 and in Chengdu in 2016. When asked to recall her experience at these events, she explained:

The first day they have a big meeting with officials, from Taiwan and China. I don't think there is any meaning. We don't like those slogans, 'harmony', 'build our society', 'you are important', 'we want to offer some service to marriage across the Strait' and so on and so forth ... yet the second day, I think it's important, because there was a professor, a psychologist, and he interviewed me to find out how I do my work and about my NGO in Taiwan. I think this is very important, because nobody like me, at that time, had such experience as a social worker in Taiwan. ${ }^{57}$

Xuli did not take on board the political mission of cross-Strait unification. Cautious with regard to Beijing's political slogans, she shared a critical angle which revealed the complexity of beliefs and perspectives these migrants could develop. As she continued:

They are willing to use feelings and emotions. We are a family; we have the same ancestors.

56

Interview, 8 October 2016, Taipei.

Skype conversation with mainland spouse, 16 September 2016. 
But it's a different thing. Take my son. He also shares the same blood. We have the same ancestors, but if you tell him that we have the same ancestors, this does not make sense to him. It's OK for my generation. You can persuade me. But what about the next generation? We have different political conditions. You can't say that we should have unification because we have the same ancestors. We can't persuade Taiwanese people! ${ }^{58}$

Even Xuefei, the informant who was part of the leadership of the pro-unification political party in Taiwan, used her political commitment to cross-Strait unification for personal aims, namely to increase her business opportunities in China, by performing her identity as one of the first migrants who was involved in setting up a pro-unification party in Taiwan.

It is often taken for granted that mainland spouses, as citizens of China, contribute to disseminating the political aims of Beijing. The truth is that mainland spouses are not just Chinese, nor are they just cross-Strait family members. Their social locations and roles are multiple and pertain to both Taiwan and China. Their multiple roles and locations also shape how they engage with and re-enact Beijing's actions. Hence, if some marriage migrants decided to advance the political agenda of Beijing, many others had other aims on their agenda. A rich variety of personal, family and collective aims emerge from their narratives: enjoying the experience of going back to China; having the chance to talk to officials in China; using their privileged position to exert their influence in local matters in their villages in China; taking the opportunity to establish other kinds of cooperation with social and economic actors in China; being staged with a new identity which gave them back the pride and dignity they had lost when they moved to Taiwan. These different points of departure also shaped the point of arrival of their activities, often somewhere outside of Beijing's nationalist objectives. 


\section{Conclusion}

With China rising as a global power, its public diplomacy strategies have become increasingly differentiated and sophisticated. The literature tends to focus on the state's strategies and aims in Beijing's public diplomacy. Yet this paper has suggested a different approach, shedding light not only on a state's actions but also on social actors' responses to the state's initiatives. Through this analysis, this paper has provided a timely account of Beijing's non-traditional diplomacy in the context of cross-Strait relations as a constructed and gendered process.

As this analysis has shown, Beijing integrated a previously overlooked group in its crossStrait diplomacy, namely cross-Strait marriage migrants. It engaged this group in several exchange activities, promoted their inclusion in the imagined national community of a unified China, and generated a new narrative that compared the cross-Strait family to its main political aim of unification across the Taiwan Strait. In the case of a phenomenon involving a majority of women who move for family reasons, Beijing developed a narrative enriched by gender connotations, by celebrating migrant women's roles as mothers of the nation, their families as symbols of cross-Strait unity, their modern lives and their beauty as a reflection of a new rising China. As a unique example of China's public diplomacy, this case has shown the adaptive nature of Beijing's public diplomacy, when new social groups start to acquire strategic importance. Yet this paper has also stressed the dynamic and relative nature of official initiatives and policies, when migrant communities may be in a position to appropriate and redefine the main narrative of the state and adjust it to their own agenda. This point is crucial in the context of public diplomacy strategies developed by a strong and authoritarian state like Beijing. Defying a mainstream narrative that sees Beijing's relations with Chinese social actors as a one-way phenomenon, the narrative and experiences of my informants instead shed light on the fact that there are opportunities of negotiation, change and rupture. Although areas of divergence and rupture between the official agenda and that of the migrants did not necessarily weaken Beijing's official narrative, they constituted an important point of departure 
for reflecting on the different interests that social actors may have when engaging with Beijing and its policies.

\section{References}

Bislev, Ane. 'The Chinese dream: imagining China'. Fudan Journal of Human and Social Sciences 8 (2015): 585-95.

Cheng, Isabelle, Lara Momesso and Dafydd Fell. 'Asset or liability: transnational links and political participation of foreign-born citizens in Taiwan'. International Migration (2018); https://doi.org/10.1111/imig.12534.

deLisle, Jacques. 'Soft power in a hard place: China, Taiwan, cross-Strait relations and US policy'. Orbis 54, 4 (Fall 2010): 493-524.

D'Hooghe, Ingrid. 'The rise of China's public diplomacy'. In The Limits of China's Soft Power in Europe: Beijing's Public Diplomacy Puzzle. Edited by Ingrid D'Hooghe (Hague: Netherlands Institute of International Relations, 2010).

D’Hooghe, Ingrid. Diplomatic Studies: China's Public Diplomacy (Leiden: Brill Nijhoff, 2014).

Friedman, Sara. 'Marital immigration and graduated citizenship: post-naturalisation restrictions on mainland Chinese spouses in Taiwan'. Pacific Affairs 83, 1 (2010): 73-93.

Friedman, Sara. Exceptional States. Chinese Immigrants and Taiwan Sovereignty (Oakland: University of California Press, 2015).

Gamlen, Alan. 'Diaspora engagement policies: what are they, and what kinds of states use them?' Working paper no. 06-32 (Oxford: University of Oxford, Centre on Migration, Policy and Society (Compas), 2006); http://essays.ssrc.org/remittances_anthology/wp-content/uploads/2009/08/Topic 19 Gamlen.pdf.

Ho, Elaine L., and Fiona McConnell. 'Conceptualizing “diaspora diplomacy”: territory and populations betwixt the domestic and foreign'. Progress in Human Geography 43, 2 (2019): 235-55.

Hsia, Hsiao-chuan. 'Imaged and imagined threat to the nation: the media construction of the "foreign brides" phenomenon as social problem in Taiwan'. Inter-Asia Cultural Studies 8, 1 (2007): 55-85.

Keng, Shu, and Gunter Schubert. 'Agents of Taiwan-China unification? The political roles of Taiwanese business people'. Asian Survey 50, 2 (2010): 287-310.

Lee, Shin-wha. 'The theory and reality of soft power: practical approaches in East Asia'. In Public Diplomacy and Soft Power in East Asia. Edited by Jan Melissen and Sook Jong Lee (New York: Palgrave Macmillan, 2011), 11-32.

Lee, Sook Jong, and Jan Melissen. 'Introduction'. In Public Diplomacy and Soft Power in East Asia. Edited by Jan Melissen and Sook Jong Lee (New York: Palgrave Macmillan, 2011), 1-10.

Leung, Maggie W.H. 'Academic mobility for development as a contested notion: an analysis of the reach of the Chinese state in regulating the transnational brains'. Tijdschrift voor Economische en Sociale Geografie 105, 5 (2014): 55872.

Lin, Gang, Ramon H. Myers, Terry Cooke and Tun-jen Cheng. 'Cross-Strait economic ties: agent of change, or a Trojan horse?' Asia Program Special Report, no. 118 (Princeton, NJ: Woodrow Wilson Center, 2003), 1-18.

Liu, Hong. The Chinese Overseas (Vol. 4: Homeland Ties and Agencies of Interaction) (Abingdon: Routledge, 2006).

Liu, Hong. 'An emerging China and diasporic Chinese: historicity, state, and international relations'. Journal of 
Contemporary China 20, 72 (2011): 813-32.

Liu, Shan-Jan Sarah. 'Chinese migrant wives in Taiwan: claiming entitlements, resisting inequality, and rejecting citizenship'. International Feminist Journal of Politics 21, 4 (2019): 617-38.

Louie, Andrea. Chineseness across Borders: Renegotiating Chinese Identities in China and the United State (Durham, NC: Duke University Press, 2004).

Ma Mung, Emmanuel. 'Chinese migration and China's foreign policy in Africa'. Journal of Chinese Overseas 4, 1 (2008): 91-109.

Mahoney, Joseph Gregory. 'Interpreting the Chinese Dream: an exercise of political hermeneutics'. Journal of Chinese Political Science 19, 27 (2014): 15-34.

Melissen, Jan, ed. The New Public Diplomacy: Soft Power in International Relations (Basingstoke: Palgrave Macmillan, 2007).

Metzl, Jamie. 'Network diplomacy'. Georgetown Journal of International Affairs 2 (2001): 77-87.

Momesso, Lara. 'Marriage, migration, and state interests: reflections from the experiences of marriage migrants from the People's Republic of China in Taiwan'. Asiatische Studien 70 (2016): 903-20.

Momesso, Lara, and Isabelle Cheng. 'A team player pursuing its own dreams: rights-claim campaign of Chinese migrant spouses in the migrant movement before and after 2008'. In Taiwan's Social Movements under Ma Yingjeou: From the Wild Strawberries to the Sunflowers. Edited by Dafydd Fell (Abingdon: Routledge, 2017).

Momesso, Lara, and Chun-yi Lee. 'Transnational mobility, strong states and contested sovereignty: learning from the China-Taiwan context'. Asian and Pacific Migration Journal 26, 4 (2017): 459-79.

Momesso, Lara, and Chun-yi Lee. 'Nation, migration, identity: learning from the cross-Strait context'. International Migration (2019); https://doi.org/10.1111/imig.12576.

National Immigration Office (Ministry of Interior). 'Statistical data of foreign spouses and mainland (Hong Kong and Macao included) spouses in each county and city according to their status (各縣市外籍配偶人數與大陸 (含港澳) 配 偶人數按證件分)' (2019); https://www. moi.gov.tw/stat/index.aspx (accessed 20 January 2020).

Niou, Emerson M.S., Peter C. Ordeshook and Guofu Tan. 'Taiwanese investment in mainland China as a policy tool'. Issues and Studies 28, 8 (1992): 14-31.

Ramo, Joshua Cooper. The Beijing Consensus: Notes on the New Physics of Chinese Power (London: Foreign Policy Centre, 2004).

Romberg, Alan D. 'Cross-Strait relations: portrayals of consistency calm on the surface, paddling like hell underneath'. China Leadership Monitor 45 (Fall 2014): 1-26.

Scheiwiller, Staci Gem. 'Introduction: setting the stage'. In Performing the Iranian State: Visual Culture and Representations of Iranian Identity. Edited by Staci Gem Scheiwiller (New York: Anthem Press, 2013).

Shih, Shu-mei. 'Gender and a new geopolitics of desire: the seduction of mainland women in Taiwan and Hong Kong media'. Signs 23, 2 (1998): 287-319.

Suryadinata, Leo. The Rise of China and the Chinese Overseas. A Study of Beijing's Changing Policy in Southeast Asia and Beyond (Singapore: IEAS Publishing, 2017).

Torab, Azam. Women and Gender: The Middle East and the Islamic World. Performing Islam. Gender and Ritual in Iran (Boston: Brill, 2006).

Tseng, Yen-fen. 'Marriage migration to East Asia. Current issues and propositions in making comparisons'. In Asian Cross-border Marriage Migration. Demographic Patterns and Social Issues. Edited by Melody Lu and Wen-shan Yang (Amsterdam: Amsterdam University Press, 2010), 31-45. 
Tu, Edward Jow-Ching, and Li Shaomin. 'Inter-regime marriage and mobility: the case of mainland China and Taiwan'. Journal of Contemporary China 8, 22 (1999): 499-516.

Turner, Simon. 'Staging the Rwandan diaspora: the politics of performance'. African Studies 72, 2 (2013): $235-6$.

Wang, Gungwu. 'Greater China and the Chinese overseas'. The China Quarterly, Special Issue: Greater China 136 (December 1993): 926-48.

Wang, Pan. 'Media presentations of cross-Strait marriage in contemporary China'. China Media Research 11, 2 (2015): 17-28.

Wang, Zheng. 'The Chinese Dream: concept and context'. Journal of Chinese Political Science 19 (2014): 1-13.

Wu, Hsing-hsin. Bridging the Strait: Taiwan, China, and the Prospects for Reunification (Hong Kong: Oxford University Press, 1994).

Xiang, Biao. Promoting Knowledge Exchange through Diaspora Networks (the Case of People's Republic of China) (Report for the Asian Development Bank) (Oxford: ESRC Centre on Migration, Policy and Society (COMPAS), University of Oxford, 2005).

Xiang, Biao. 'A new mobility regime in the making: what does a mobile China mean to the world?' Global Governance 10 (2007): 1-19.

Yang, Alan H. 'Unpacking Taiwan's presence in Southeast Asia: the international socialisation of the New Southbound Policy'. Issues and Studies: A Social Science Quarterly on China, Taiwan and East Asian Affairs 54, 1 (2018): 1840003-33.

Yang, Rui, and Anthony R. Welch. 'Globalisation, transnational academic mobility and the Chinese knowledge diaspora: an Australian case study'. Discourse: Studies in the Cultural Politics of Education 31 (2010): 593-607.

Yang, Wang-ying, and Ping-rong Lee. 'The citizenship dilemma of mainlander spouses in Taiwan: the conspiracy of nationalism and patriarchy (大陸配偶的公民權 困境一國族與父權的共謀)' (in Chinese). Taiwan Democracy Quarterly (臺灣民主季 刊) 6, 3 (2009): 47-86.

Yun, Seong-Hun, and Elizabeth L. Toth. 'Future sociological public diplomacy and the role of public relations: evolution of public diplomacy'. American Behavioural Scientist 53, 4 (2009): 493-503.

Zhao, Kejin. 'The motivation behind China's public diplomacy'. The Chinese Journal of International Politics 8, 2 (2015): 167-96; doi: 10.1093/cjip/pov005.

\section{RATS articles (in chronological order)}

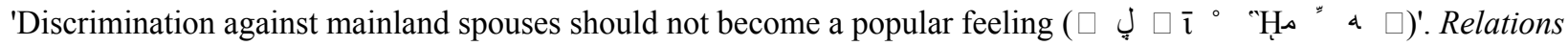
Across Taiwan Straits (RATS), February 2002, 22.

'The mainland spouses I have seen ( 45-7.

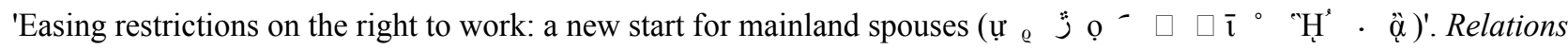
Across Taiwan Straits (RATS), November 2008, 37-8.

'The spring breeze dissolves many layers of snow: the water of the sea links hearts across the Strait. Looking at cross-

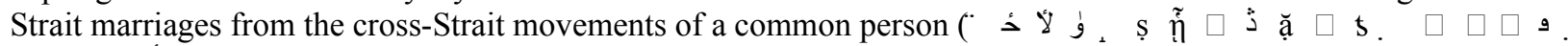

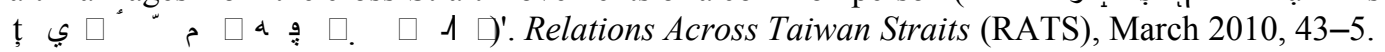

'Serving cross-Strait sweet cause and common effort. Interview with Dou Yupei, Deputy Minister for Civil Affairs and

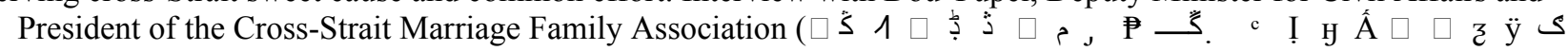




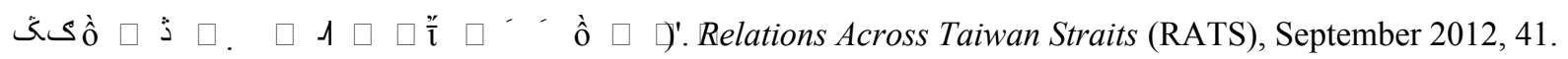

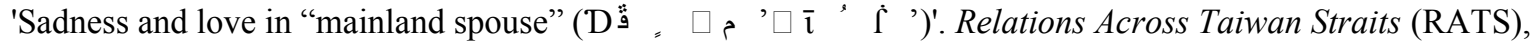
September 2012, 50-52.

'Sharing happiness, cheering up for love. Report of the second Cross-Strait Marriage Family Forum ( $\square$ ậ $j \bar{\xi} \square, \hat{Y}$

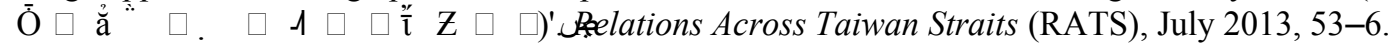

